UDC 632.15: 504.6: 574

\title{
THE PROBLEMS OF THE NEGATIVE ENVIRONMENTAL IMPACT OF CHEMICAL POLLUTANTS AND POSSIBLE WAYS OF THEIR PREVENTION
}

\author{
H. Kh. Khalilova ${ }^{1,2}$ \\ ${ }^{1}$ Institute of Physics \\ National Academy of Sciences of Azerbaijan \\ 33, H. Javid ave., AZ 1143, Baku \\ ${ }^{2}$ Interrnational Ecoenergy Academy \\ 5,M. Rahim str., AZ 1073, Baku; e-mail: khalilova@rambler.ru
}

Received 31.10.2019

\begin{abstract}
The paper discusses the problems of environmental pollution with harmful chemicals and their adverse effects on ecosystem components. The main sources of harmful chemicals discharged into the atmosphere air, soil and water basins are specified. Potential threats of toxic organic compounds, heavy metals, radionuclides, as well as exhaust gases to both the natural environment and living organisms are examined. In addition, the results of the author's researches in the fields of environmental pollution in the territories exposed to various anthropogenic sources and effective methods to prevent their negative environmental impact are presented.
\end{abstract}

Keywords: oil, chemical pollutants, ecosystem, radionuclides, adsorption, photocatalysis DOI: 10.32737/2221-8688-2019-4-500-517

\section{Introduction}

Environmental pollution is aserious concern in many industrially developed and urbanized regions worldwide. The pollution occurs due to physical impact as well asexcessive amounts of chemical compounds and biological agents in ecosystem that result in the change of the natural pecularities of its components.

The roles of the physical (mechanical, radioactive, electromagnetic, thermal, sound and light impact), biological (the impact of biotic, micro- and macro-biological processes) and chemical factors in the ecosystem pollution are different [1-4].

Toxic hazardous wastes are defined as containing chemicals posing substantial risk to both human health and the environment when improperly treated, stored, transported or disposed. Scientific studies have shown that these wastes have toxic, carcinogenic, mutagenic, or teratogenic effects on human or other life forms [5-7].

The majority of hazardous waste is generated by the chemical manufacturing,petroleum, pesticides and processing industries.

According to the researches carried out in this area, the chemical pollutants can be divided into the following groups:

- oil and oil products;

- heavy metals and biologically nondegradable synthetic organic compounds;

- biologically degradable organic compounds;

- low toxic inorganic compounds (they basically include inorganic salts);

- biogenic substances.

Oil and oil products are considered to bemost priority pollutants due to their toxicity, migration and accumulation ability. It is well known that oil and gas resources development, transportation and use are followed by release of a large amount of hazardous substances into the environment. Getting in the environment these compounds change physico-chemical and biological properties of soil, air and water 
systems causing negative impact on natural biochemical processes $[8,9]$.

Problems of chemical pollution of the environment concern all the industrially developed regions worldwide including the Absheron peninsula that have long been one of the oil producing provinces of the world. The substantial reviews of the environmental effects of most dangerous chemical substances to apply appropriate methods of their prevention are of great importance. This article provides extensive information on the adverse effects of toxic chemical contaminants on the ecosystem components, as well as the results derived from the studies of chemical pollution in an area that have been long-term exposure to anthropogenic sources and effective methods of prevention.
The atmospheric air, soil, and water samples used during the researches were collected from the Absheron industrial areas.

Laboratory analyses were conducted using the following methods:

- the total amount of oil hydrocarbons in soil samples was determined by a gas chromatograph flame-ionization detector (GC-FID), the amount of polynuclear aromatic hydrocarbons(PAH) was determined by the gas chromatograph-mass spectrometer (GC-MS), and the percentage of oil by termo-graphic method;

- the analysis of most heavy metals (As, $\mathrm{Ba}, \mathrm{Cd}, \mathrm{Cr}, \mathrm{Cu}, \mathrm{Fe}, \mathrm{Mn}, \mathrm{Pb}$ and $\mathrm{Zn}$ ) was determined in inductively coupled plasma optical emission spectrometer (ICP-OES) after treatment with nitric acid in a solid microwave oven. Atomic fluorescence method was used in the determination of mercury $(\mathrm{Hg})$;

- phenols were measured using photometric method;

- the amount of radionuclides was determined by gamma-spectrometer;

- chemical oxygen demand (COD) in water samples was determined by bichromate method with colorimetric measurement;

- the analyses of $\mathrm{CO}, \mathrm{NO}_{\mathrm{x}}$ and $\mathrm{SO}_{2}$ gases in atmospheric air were conducted in Testo-305 device, the amount of hydrogen-sulfide $\quad\left(\mathrm{H}_{2} \mathrm{~S}\right) \quad$ was determined through reacting with $\mathrm{Na}$ arsenite and $\mathrm{Ag}$-nitrate forming $\mathrm{Ag}_{2} \mathrm{~S}$ and the amount of dust by gravimetric method.

\section{Results and discussion}

Both anthropogenic and natural sources are responsible for environmental pollution during oil-gas operations. Crude oil, natural gas, produced water and rocks are natural sources of environmental pollution [10].

Oil has very complex chemical content. It constitute of alkanes, cycloalkanes, hundreds of unsaturated aliphatic and aromatic hydrocarbons as well as heteroxyclic compounds containing little amounts of nitrogen, oxygen, sulphur, metals and radionuclides $[11,12]$.

All factions of crude oil have certain amount of trace elements. From the ecological viewpoint, they are divided into two groups: toxic and non-toxic. Among them $\mathrm{Si}, \mathrm{Fe}, \mathrm{Al}$, $\mathrm{Mn}, \mathrm{Ca}, \mathrm{Mg}$ and $\mathrm{P}$ are low toxic microelements. $\mathrm{V}, \mathrm{Ni}, \mathrm{Co}, \mathrm{Pb}, \mathrm{Cu}, \mathrm{As}, \mathrm{Hg}$ and
$\mathrm{Zn}$ have negative impact on biocenosis at high concentrations [13]. About $10^{-3} \%$ toxic metals and halogens are found in the asphaltene-tar fraction of oils. Some of metals are in the form of salts of organic acids, and others in the form of chelat complexes.

Among other natural pollutants, produced water is more hazardous for the environment. Itcontains various ions, oil and dissolved gases, such as $\mathrm{CO}_{2}$ and $\mathrm{H}_{2} \mathrm{~S}$. Both the oil polluted rocks and produced watercause pollution of the environment, first of all soil cover. The rocks obtained from oil extraction may constitute of $1-5 \%$ even $10 \%$ hydrocarbons. Depending on the pollution level, they can form complex substances with $\mathrm{Fe}$ and $\mathrm{Al}$ ions and various soluble complexes thus leading to the depletion of important 
minerals in soil. Light fractions of hydrocarbons easily migrate to deeper sections of soil, and therefore, increased content of heavy fractions are accumulated in the upper layers. The heavy fraction of hydrocarbonsare toxic and degrade difficultly[14].

Drilling solutions and drill cuttings are by volume the largest anthropogenic waste discharged when exploring and development of oil fields. Besides, man-caused pollutants include also water-oil emulsions, corrosion inhibitors, surface active agents, $\mathrm{Ca}\left(\mathrm{NO}_{3}\right)_{2}$, $\mathrm{Mg} \quad\left(\mathrm{NO}_{3}\right)_{2}, \mathrm{HCl}, \mathrm{KCl}, \mathrm{NaON}, \mathrm{NH}_{4} \mathrm{ON}$, various polymers and mechanical mixtures, etc. $[10,15]$.

The hazardous pollution level of any toxic substance in ecosystem is determined according to its generally accepted maximum permissible concentration (MPC). MPC of oil and oil products(including diezel fuel, heavy oil and kerocene, etc.) in soils has not been identified up to the present time. Oil pollution level of soils is evaluated through comparising with its background concentration (BC) for concrete territories. The geochemical background level of oil hydrocarbons in soils is accepted to be within $0,01-0,05 \mathrm{~g} / \mathrm{kg}$ in the European countries and $100 \mathrm{mg} / \mathrm{kg}$ (i.e. $0,01 \%$ ) for the soils of oil producing territories of Russia and Azerbaijan [16, 17].

It is important to study self-purification processes when conducting researches on the hazards of oil pollution to the environment or to the population health. Self-purification is understood as a whole of natural processes that lead to the degradation, transformation and utilization of the contaminants.

In the environment, oil hydrocarbons are subjected to various changes depending on local conditions. Microbial degadation of hydrocarbons occur under microbes influence. However, microorganisms activity is very low in the oil polluted soils. Therefore, the microbial degradation of such light fractions of oil as n-paraffins, phenols and thiols, etc.proceed very slowly. The asphaltene-tar fraction of oil is more environmentally dangerous, because of their nonbiodegradability [18].

Table 1 presents the results of our studies on soil pollution carried out in the territory of anoil production enterprise. The data have shown that the pollution of soil by organic products is changing in a wide interval within the study site. The contents of total petroleum hydrocarbons (TPH) in some areas are variable from 0.78 to $26.9 \%$, against the BC.There were several supressed oil wells in the study territory. Despite that the wells supressed many years ago, the territory was continuously subjected to oil spill, drill cuttings and other pollutants that resulted in the accumulation of a huge amount of hydrocarbons in soil. As can be seen from the table, concentration of hydrocarbons exceeded BC in all samples. Studies showed that the amount of oil products was gradually decreasing, reaching $0-3.23 \%$ at a depth of 1.5 $\mathrm{m}$. At the same time, increased levels of PAH and phenols was recorded in the majority of samples during the studies.

Table 1. Contents of organic pollutants in oil polluted soils

\begin{tabular}{|c|c|c|c|c|c|c|c|c|c|}
\hline \multirow{2}{*}{$\begin{array}{c}\text { Soil } \\
\text { samples }\end{array}$} & \multicolumn{2}{|c|}{ Site 1 } & \multicolumn{3}{|c|}{ Site 2 } & \multicolumn{3}{c|}{ Site 3 } \\
\cline { 2 - 10 } & $\begin{array}{c}\text { TPH, } \\
\text { ( }\end{array}$ & $\begin{array}{c}\text { Phenols, } \\
\mathrm{mg} / \mathrm{kg}\end{array}$ & $\begin{array}{c}\text { PAH, } \\
\mathrm{mkg} / \mathrm{kg}\end{array}$ & $\begin{array}{l}\text { TPH, } \\
\%\end{array}$ & $\begin{array}{c}\text { Phenols, } \\
\mathrm{mg} / \mathrm{kg}\end{array}$ & $\begin{array}{c}\text { PAH, } \\
\mathrm{mkg} / \mathrm{kg}\end{array}$ & $\begin{array}{l}\text { TPH, } \\
\%\end{array}$ & $\begin{array}{c}\text { Phenols, } \\
\mathrm{mg} / \mathrm{kg}\end{array}$ & $\begin{array}{c}\text { PAH, } \\
\mathrm{mkg} / \mathrm{kg}\end{array}$ \\
\hline 1 & 20.6 & 0.081 & 0.0011 & 9.6 & 0.052 & 0.0021 & 8.8 & 0.042 & 0.0013 \\
\hline 2 & 9.7 & 0.047 & 0.0014 & 18.5 & 0.084 & 0.0032 & 17.2 & 0.076 & 0.0017 \\
\hline 3 & 9.9 & 0.049 & 0.0012 & 19.3 & 0.081 & 0.0029 & 13.9 & 0.043 & 0.0015 \\
\hline 4 & 9.5 & 0.048 & 0.0008 & 9.8 & 0.049 & 0.0020 & 17.1 & 0.075 & 0.0018 \\
\hline 5 & 10.0 & 0.050 & 0.0007 & 23,6 & 0.087 & 0.0034 & 13.6 & 0.042 & 0.0016 \\
\hline 6 & 5.7 & 0.037 & 0.0005 & 8.7 & 0.044 & 0.0017 & 5.3 & 0.081 & ND* \\
\hline 7 & 2.3 & 0.023 & 0.0003 & 20.0 & 0.083 & 0.0030 & 18.9 & 0.080 & 0.0028 \\
\hline 8 & 0.8 & 0.016 & 0.0002 & 24.7 & 0.086 & 0.0036 & 22.8 & 0.076 & 0.030 \\
\hline
\end{tabular}




\begin{tabular}{c|c|c|c|c|c|c|c|c|c|}
\hline \hline 9 & 9.8 & 0.062 & 0.0033 & 26.9 & 0.088 & 0.0035 & 20.8 & 0.078 & 0.0028 \\
\hline
\end{tabular}

As it was mentioned above, the asphaltene-tar fraction of oil containthe most toxic environmental pollutants - heavy metals. Potential threat of heavy metals to ecosystem components, especially to human health, is associated with two factors: high toxic impact on living organisms at low concentrations and bioaccumulation abilities. Many of them like $\mathrm{Hg}, \mathrm{Pb}, \mathrm{Cd}, \mathrm{Cr}, \mathrm{Zn}$ and $\mathrm{Cu}$ can be very toxic to the ecosystem. Heavy metals are mainly gathered in soils and bottom sediments. Concentrated in soils heavy metals can be adsorbed and accumulated in different parts of plants through root system. One of the major global problems of the present days - acid rains can wash heavy metals from soil rocks into lakes, rivers and bays. Majority of heavy metals have strong affinity for sulfur and disrupt enzyme function forming bonds with sulfur groups in enzyme and may eventually kill fish, birds and mammals. Being interacted with other components of ecosystem, soil becomes the main source of most heavy metals entering human organism [19].

The negative effects of heavy metal contamination areviewed as global concern.
The results of researches dealing with the impact of oil contamination on the soils microbiological peculiarities and plants showed that the cereals cultivated in these soils contain high quantity of $\mathrm{Pb}, \mathrm{Cd}, \mathrm{Fe}, \mathrm{Ni}$, $\mathrm{Zn}$ and $\mathrm{Cu}$. In comparision with non-polluted soils, the number of heterotroph bacteria is $89 \%$ lower in oil polluted soils. It was revealed that high concentration of heavy metals in the oil polluted soils not only affects the plant quality, and also reduces the number and activity of microbes [20].

The results derived from our studies on the heavy metal pollution of soils in one of the oil polluted area are presented in Table 2 . The results indicate that the amount of $\mathrm{Cr}, \mathrm{Cu}$ and $\mathrm{Zn}$ in several samples exceeded their MPC and BC. Despite the fact that the level of Ni in all samples was increasingly higher its MPC, it exceeded the $\mathrm{BC}$ only in one site. The concentration of $\mathrm{Hg}$ exceeded its $\mathrm{BC}$ in two samples. The lowest values were recorded for $\mathrm{Cd}$ throughout the study site that can be attributed to the lithologic composition of soils.

Table 2. Concentration of heavy metals in oil contaminated soils

\begin{tabular}{|c|c|c|c|c|c|c|}
\hline Soil samples & \multicolumn{6}{|c|}{ Heavy metals (mg/kg) } \\
\cline { 2 - 7 } & $\mathrm{Cd}$ & $\mathrm{Cr}$ & $\mathrm{Cu}$ & $\mathrm{Ni}$ & $\mathrm{Hg}$ & $\mathrm{Zn}$ \\
\hline 1 & 0.29 & 77.6 & 67.8 & 79.0 & 0.0450 & 66.2 \\
\hline 2 & 0.15 & 59.1 & 39.7 & 48.5 & 0.0082 & 15.8 \\
\hline 3 & 0.27 & 63.5 & 35.4 & 56.2 & 0.0059 & 74.5 \\
\hline 4 & 0.20 & 47.2 & 176 & 53.8 & 0.0062 & 102 \\
\hline 5 & 0.42 & 81.5 & 159 & 71.7 & 0.0436 & 34.1 \\
\hline 6 & 0.57 & 113 & 45.5 & 69.8 & 0.0080 & 19.6 \\
\hline 7 & 0.34 & 65.5 & 161 & 115 & 0.0310 & 22.4 \\
\hline MPC(mg/kg) & 1.0 & 6.0 & 3.0 & 4.0 & $2.1 *$ & 23 \\
\hline BC $(\mathrm{mg} / \mathrm{kg})$ & 3.0 & 40 & 100 & 100 & 0.4 & 70 \\
\hline *Note: $\mathrm{MPC}$ of 2.1 for Hg is accepted for the areas away from residential areas
\end{tabular}

Usually, the water produced during oil extraction constitute of the water soluble fractions of oil - the aromatic fractions boiling at low temperature and alkyl phenols [21]. Oill and oil products are exposure to a number of processes when getting in water system. These processes result in their degradation and transformation to other products. First of all, the valotile fraction of oil evaporates. This processis itensified by the ambient 
temperature, wind speed and water flow. The evaporation reaches $60 \%$ at $6-8 \mathrm{~m} / \mathrm{s}$ wind speed.Water solubility of oil increases depending on the water temperature $\left(>3^{\circ} \mathrm{C}\right)$. Increased content of paraffin hydrocarbons in oil decreases its water solubility. A part of hydrocarbons form a thin film on the water surface or emulsion and the remaining part accumulate in the bottom. A huge amount of hydrocarbons accumulate in bottom sediments because of their non-degradability in anaerob condition [22]. Accumulated in the bottom sediments of water basins they can migrate into deep sections of soils in surrounding areas (Fig. 1). Self-purification of oil polluted water occurs by evaporation, chemical oxidation and microbial degradation. The researches of specialists suggested that during oil spills about $12 \%$ of oil can be reduced by evaporation at $2-5{ }^{\circ} \mathrm{C}$ and $25 \%$ of oil can be reduced at $22-25^{\circ} \mathrm{C}$ within three days [23]. Microbiological degradation of cycloalkanes is more difficult compared to n-alcanes. Microbiological degradation of aromatic hydrocarbons is longterm process depending on the numbers of nucleus. Aromatic compounds having three or more condensed nucleuses are very persistent to the microbial influence. Compared to other aromatic hydrocarbons, the degradation of naphthalene, toluol and ethyl-benzene proceeds more easily $[24,25]$.

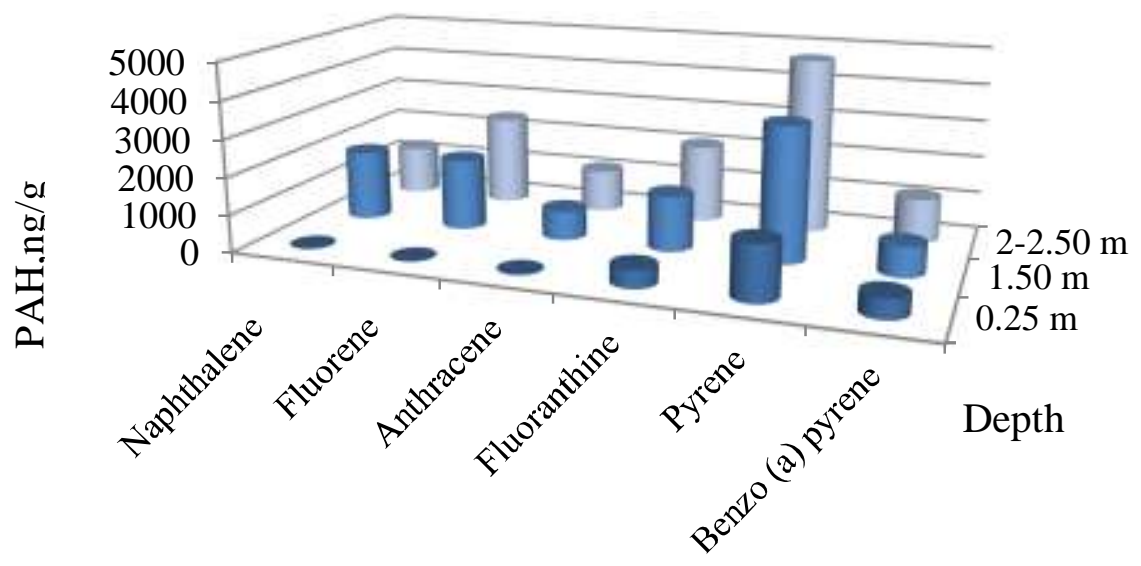

Fig. 1 Change of PAH content at different depths of sampling well around the oily lake

Among other oil hydrocarbons PAH are especially dangerous for ecosystem. PAH are also obtained during the use of hydrocabons and other carbon containing fuels. PAH released into atmosphere due to fossil fuel burning spread over long distances. The most dangerous for human health PAH bezo(a) pyren is mainly found in exhaust gases.

The are a series of researches in the field of PAH formation, their persistence and potential impact on ecosystem. PAH pollution occurs during oil production and also burning conventional fuels in oxygen deficit environment. Along with natural sources, heating systems, energy stations using petroleum and carbon fuel and exhaust gases are major anthropogenic sources of PAH. Getting in atmosphere from various athropogenic sources, PAH form suspended particles that can spread to large territories and transform to other pollutants through photochemical reactions. Further, these pollutants return to the earth surface and accumulate in soils and bottom sediments of surface waters [26, 27].

PAH are activated under solar irradiation. Photoactivated PAH molecules directly damage skinor result in the formation of oxygen radicals causingmore threat for all alive organisms. Having $\pi$-bonds in thier structure, $\mathrm{PAH}$ are the most dangerous photoactive pollutants. The works of specialists confirm that hydrocarbon and heavy metal polluted sediments create serious hazard to aquatic communities[28].

In large cities, exhaust gases and industrial discharges are the main sources of atmosphere pollution. Exhaust gases are rich in $\mathrm{CO}_{2}, \mathrm{CO}$, water steam, $\mathrm{NO}_{\mathrm{x}}$ and heavy 
metals. Depending on conditions, from 100 to 170 chemical compounds including aliphatic, alicyclic and aromatic hydrocarbons can be found in exhaust gases.

Carbon-monoxide $(\mathrm{CO})$ produced as a result of fossil fuel burning under oxygen deficit condition is very dangerous for human life. In human organism, CO connects with haemoglobin in blood forming $\mathrm{CO}$ Haemoglobin that disturbs the oxygen transfer and normal function of blood.

The researches carried out along the transport roads have revealed the accumulation of heavy metals and cancerogenic $\mathrm{PAH}$, especially benzo(a)-pyrene $\left(\mathrm{C}_{20} \mathrm{H}_{12}\right)$, in soils at $10-20$, even $100-200 \mathrm{~m}$ distances. It is a known fact that the accumulation of contaminants in plants, soil and water basins lead to various unfavorable consequences[27, 29] .

As a result of the use of fossil fuels including natural gas, oil and oil products and coal $\mathrm{SO}_{2}, \mathrm{NO}, \mathrm{CO}_{2}$ and $\mathrm{CO}$ are released to atmosphere. Usually, sulphur containing products $-\mathrm{SO}_{2}, \mathrm{H}_{2} \mathrm{~S}$ and $\mathrm{H}_{2} \mathrm{SO}_{4}$ are observed in the discharges of oil-gas refining and thermal energy stations. Transport, energy stations and industrial enterprises are the anthropogenic sources of nitrogen compounds - $\mathrm{NO}, \mathrm{NO}_{2}$, $\mathrm{HNO}_{3}$. The results of our recent observations on the Absheron industrial region have revealed increased concentrations of some of the abovementioned gases in atmosphere air (table3).

Table 3. The content of atmosphere pollutants in industrial area

\begin{tabular}{|c|c|c|c|c|c|}
\hline \multirow{2}{*}{ Samples } & \multicolumn{5}{|c|}{ Pollutants, $\mathrm{mg} / \mathrm{m}^{3}$} \\
\cline { 2 - 6 } & $\mathrm{SO}_{2}$ & $\mathrm{CO}$ & $\mathrm{NO}_{2}$ & $\mathrm{H}_{2} \mathrm{~S}$ & Dust \\
\hline 1 & 0.67 & 4.5 & 0.136 & 0.010 & 0.190 \\
\hline 2 & 1.05 & 3.8 & 0.150 & 0.009 & 0.156 \\
\hline 3 & 2.10 & 3.6 & 0.095 & 0.007 & 0.210 \\
\hline 4 & 0.70 & 7.3 & 0.170 & 0.010 & 0.128 \\
\hline 5 & 0.30 & 2.9 & 0.085 & 0.009 & 0.143 \\
\hline 6 & 1.20 & 6.1 & 0.090 & 0.006 & 0.208 \\
\hline $\mathrm{MPC}, \mathrm{mg} / \mathrm{m}^{3}$ & 0.5 & 3.0 & 0.085 & 0.008 & 0.16 \\
\hline
\end{tabular}

Emmission of $\mathrm{SO}_{2}$ and $\mathrm{NO}_{2}$ to atmosphere cause one of the global problems of today - acid rains. $80 \%$ of $\mathrm{SO}_{2}$ gas are emitted to atmosphere from thermal energy stations, industrial enterprises and heating of buildings [26].

The environmental impact of nitrogen oxides has been ignored for many years and has not been properly evaluated. As it was already mentioned above, major part ofNO $\mathrm{x}_{\mathrm{x}}$ ases is released from stationary sources using conventional fuel. $95 \%$ of nitrogen falls into atmosphere in a form of monoxide $-\mathrm{NO}$ and than oxidizes formingNO $\mathrm{N}_{2}$. The effect of nitrogen oxides on ecosystem occurs by the following three ways:

1. $\mathrm{NO}$ and $\mathrm{NO}_{2}$ gases penetrate into the plant body through the pores of cells and intensify their growth, while decreasing stability to other factors. The experiments conducted on the plants growen under $\mathrm{NO}_{2}$ and $\mathrm{O}_{3}$ (ozone) conditions showed that the combined effect of these gases is more harmful than their individual effects.

2. In troposphere, gaseous hydrocarbons, ozone and nitrogen oxides $\left(\mathrm{NO}, \mathrm{NO}_{2}\right)$ are interacting under solar irradiation and form secondary pollutants photochemical products. Olefines, benzo(a) pyrene, aldehydes, ozone, peroxyacetyl nitrate (PAN) and peroxyibenzoil nitrate $\left(\mathrm{PB}_{2} \mathrm{~N}\right)$ and photochemical smogare pollutants formed as a result of photochemical reactions. 
3. The 3rd environmental effect of $\mathrm{NO}_{\mathrm{x}}$ gases occur through their interaction with water in atmosphere forming acid rains.

The impact of acid rains on ecosystem is associated witha number of negative consequences as the increase of theacidity of lakes and ground waters, damage and destruction of plants, deforestation, deterioration of constructions and corrosion of metal structures, etc. The increase of acidity in water basins result in the accumulation of toxic heavy metals, especially $\mathrm{Hg}$, in fish organism causing serious threat for human health.

All the activities related to the production and use of energy resources lead to the pollution of atmosphere by greenhouse gases $-\mathrm{CO}_{2}, \mathrm{CH}_{4}, \mathrm{H}_{2} \mathrm{O}$ steem, $\mathrm{N}_{2} \mathrm{O}$, ozone, halogenated hydrocarbons and sulfurhexafloride $\left(\mathrm{SF}_{6}\right)$ resulting in climate change and ozone layer depletion.

Ozone layer is characterized by its two important effects. In one side it absorbs UV beams protecting the Earth from harmful impact of the solar radiation. Therefore, ozone layer depletion causes serious concern worldwide [30].

The second effect of ozone layer is that when absorbing UV beams it heats stratosphere which results in temperature inversion. By this way, ozone restricts the vertical movement of pollutants facilitating their distribution to large territories. In addition, atmosphere ozone significantly influences corrosion processes. Ozone has destructive influence upon organic and inorganic materials. It destructs double carbon links in organic materials that weaken their endurance .

Among the chemical pollutants, chlorinated compounds of aromatic hydrocarbons are most dangerous for ecosystem. They are polychlorinated biphenyls (PCBs), dibenzo-p-dioxins (PCDDs), dibenzofurans (PCDFs) and related compounds [31]. PCBs are one of the widely distributed contaminants of ecosystem. In ecosystem, PCBs exist as complex mixtures changing the amount of individual components depending on both the time and natural environment. Being released into the environment, these compounds undergovarious changes and form the substances differing from initial technical mixtures. Therefore, it is difficult to determinethe PCBs risk relatingto ecosystem components. Many years, environmental impact of PCBs has attracted the attention of scientists [32, 33]. Plastic materials, dye manufacturing enterprises, hydraulic liquids and energy generators are the main sources of PCBs pollution. PCBs persist in ecosystem for many years. They accumulate in living organisms dissolving in fats. PCBs have middle valotility $\left(25^{\circ} \mathrm{C}\right.$-də $\left.10^{-2}-10^{-4} \mathrm{~Pa}\right)$ and vaporize slowly at room temperature. Their evaporation sharply increases at high temperatures. The character of distribution of PCBs pollution in the territory can be explaned by the evaporation of chlorinated organic compounds from polluted surfaces in hot seasonsand transportation in a form of aerosols to large distances with dust or atmosphere precipitations, and also by their migration in the polluted areas through sewage, surface and ground waters. Hence, the human organism can become a final accumulation place of the PCBs cycle in ecosystem. PCBs belong to the category of persistent artificial organic substances $\left(\mathrm{POP}_{\mathrm{S}}\right)$ characterised by high accumulation capability. PCBs polluted environment causes potential hazards for human health including cancerogenic effect, diseases of respiratory system and childlessness, etc. Burning of PCBs at a temperature below $1000^{\circ} \mathrm{C}$ results in the generation of more toxic compounds such as dioxins and furans. Dioxins getinto the environment with exhaust gases and during incineration of domestic waste, medicals and sewerage slags. It should be noted, that getting in the natural environment dioxins intensify toxic effects of many pollutants, especially $\mathrm{Hg}$, $\mathrm{Pb}, \mathrm{Cd}$ and other heavy metals, pesticides and metabolizm products of medicals leading to the mortality of valuable fauna species [33].

Industrially developed regions are also characterized by radioactive pollution. Radioactive pollutants can be of natural and anthropogenic origins. Radioactive elements that are found naturally in the Earth 
environmentare: ${ }^{238} \mathrm{U},{ }^{235} \mathrm{U},{ }^{232} \mathrm{Th}$ series and their respective decay products, as well as ${ }^{40} \mathrm{~K}$. Naturally occurring radioactive materials exist in soil, water, plants, animals, human, coal, lignite, petroleum, phosphate ores, geothermal waters and wastewater, etc., in small but varying amounts almost everywhere. Subjected to various technogenic processes, the natural radionuclids may change their physical state and pose a threatto all ecosystem components.

Over 30 radio-izotopes of chemical elements can be found in the aerosoles of large industrial cities. It is possible to determine their sources according to the izotope content of the aerosoles. The researches of the specialists have revealed ${ }^{60} \mathrm{Zn},{ }^{47} \mathrm{Ca},{ }^{141} \mathrm{Ce}$, ${ }^{187} \mathrm{~W}$ and ${ }^{42} \mathrm{~K}$ in the atmosphere dischages of tar manufacture, and ${ }^{86} \mathrm{Rb},{ }^{141} \mathrm{Ce},{ }^{181} \mathrm{Hf},{ }^{177} \mathrm{Lu}$, ${ }^{233} \mathrm{~Pa}$ and ${ }^{134} \mathrm{Cs}$ in the aerosoles released from asphalt-concrete manufacture and $75 \mathrm{Se}$, ${ }^{76} \mathrm{As},{ }^{177} \mathrm{Lu},{ }^{203} \mathrm{Hg},{ }^{181} \mathrm{Hg},{ }^{233} \mathrm{~Pa},{ }^{187} \mathrm{~W},{ }^{51} \mathrm{Cr}$ in the discharges of thermal energy stations [34]. Majority of these aerosoles affectthe pollution of soil and plants insignificantly. However, their presence in food products is undesirable.

Thus, all processes based on the use of materials containing radioactive substances are the sources of risk to ecosystem components, particularly to human health. From this viewpoint, the territories near to nuclear energy stations are exposure to great danger. According to experts' evaluation, as aresult of the accident happened in 2011 in Fukusima station $150 \times 10^{15} \mathrm{Bk}^{131} \mathrm{I}$ and $6-15 \times 10^{15} \mathrm{Bk}$ ${ }^{137} \mathrm{Cs}$ were released to atmosphere [34]. During the studies carried out by the Russian specialists on technogenic pollution in the Muravyov-Amur peninsula that is situated near to Fukusima station it was revealed thatcompared to early years the content of $\mathrm{Cu}$ and $\mathrm{Pb}$ exceeded MAC by 2 times, the content of other metals increased by $8-32 \%$ andthe amount of ${ }^{137} \mathrm{Cs}$ waste reached $30-300 \mathrm{kBk} / \mathrm{m}^{2}$ [35]. The studies of the Japanese specialists revealed increasingly high levels of ${ }^{137} \mathrm{Cs}$ pollution ranging from 600 to $3000 \mathrm{kBk} / \mathrm{m}^{2}$ in the soils of the territory where the accident happened [36].

The activities associated with the production and use of conventional energy resouces are potential sources of radioactive pollution.

Beginning from early XX century, radioactive pollution related to oil-gas activities have been studied worldwide, including USA, North Sea oil provinces, Canada, Australia, Egypt and Saudi Arabia, etc. [37-39]. The pollution of natural gas with radon has been known about 100 years ago. The produced water includes several radioactive elements, particularly radium-226 (Ra-226) and radium-228 (Ra-228). Radium is a product of the decay of natural radionuclides contained in rocks such as uranium (U) and thorium (Th). The concentration of $\mathrm{Ra}$ in the produced waters is higher than other radionuclides due to its water solubility. The researhes indicate, that as a result of $\mathrm{U}$ and $\mathrm{Th}$ decay $\mathrm{Bi}-212, \mathrm{Bi}-214$, Ac228, $\mathrm{Pb}-210, \mathrm{~Pb}-212$ and $\mathrm{Pb}-214$ can also be found in the produced water. However, their impact on the environment is not signifcant, because their low activity in ecosystem in comparision with Ra.In order to prevent radioactive pollution during offhsore oil-gas operations, special regulatory limits were set by the European Commission for radionuclide pollution. According to this regulation, permissible levels for ${ }^{40} \mathrm{~K},{ }^{226} \mathrm{Ra}$ and ${ }^{232} \mathrm{Th}$ are accepted to be $100 \mathrm{Bk} / \mathrm{g}, 10 \mathrm{Bk} / \mathrm{g}$ and $1 \mathrm{Bk} / \mathrm{g}$, respectively [40].

Laboratory analyses confirmed U, Th and Rapresence in the oil and produced water samples of the Absheron oil fields. The early researches of specialists showed that the quantity of $U$ is higher in methane-naphtene fraction of oils compared to paraffin-aromatic fraction and there is a genetic relation between the radionuclide composition of oil and produced water.The results of researches indicatethat the amounts of $\mathrm{Ra}$ and $\mathrm{U}$ in the upper part of the highly mineralized productive layer of the Absheron oil fields are higher than in the lower part characterised by alkaline waters [41, 42].

The studies carried out on the oil industrial territories revealed radionuclide pollution in soils, surface waters and bottom sediments [43, 44].The ecological monitorings of the last years have recorded the presence of natural and artificial radionuclides 
in soil samples collected in the vicinity of oil fields (table 4).

Table 4. The content of radionuclides in oil polluted soils

\begin{tabular}{|c|c|c|c|c|c|c|c|c|}
\hline \multicolumn{9}{|c|}{ Radionuclides, Bk/ $\mathrm{kg}^{-1}$} \\
\hline \multicolumn{4}{|c|}{ Uranium series } & \multicolumn{3}{|c|}{ Thorium series } & artificial & \multirow[t]{2}{*}{${ }^{40} \mathrm{~K}$} \\
\hline${ }^{234} \mathrm{Th}$ & ${ }^{210} \mathrm{~Pb}$ & ${ }^{214} \mathrm{~Pb}$ & ${ }^{214} \mathrm{Bi}$ & ${ }^{214} \mathrm{Bi}$ & ${ }^{208} \mathrm{Tl}$ & ${ }^{228} \mathrm{Ac}$ & ${ }^{241} \mathrm{Cs}$ & \\
\hline $46 \pm 10$ & $36 \pm 9$ & $32 \pm 3$ & $33 \pm 2$ & $32 \pm 1$ & $36 \pm 3$ & $41 \pm 4$ & $3.5 \pm 0.8$ & $741 \pm 22$ \\
\hline
\end{tabular}

The ways of preventing the ecosystem pollution by harmful chemicals

During preventing the environmental impact associated with oil, oil products and other chemicals pollution the main attention should be paid to the use of the effective and readily available materials, while developing cost-effective techniques sufficiently simple in terms of the technological process.

A number of mechanical, physicochemical, chemical and biochemical methods are used for the purification of oil polluted waters.

Among the physico-chemical methods, the adsorption method is widely applied due to its efficiency and possibility of achieving the necessary level of the pollutants removal. Plant and mineral based natural adsorbents, viskose, hydrated cellulose, synthetic fibers and polyurethane foams,etc. are used in adsorption methods [45].

Sufficient amount of resources, cheapness and non-toxicity provides great opportunity for the application of natural adsorbents. Despite the low adsorbtion capacity of natural adsorbents, the above mentioned features confirm their advantages compared to synthetic materials. Some of synthetic materials, for example polyuretane foam is capable of adsorbing oil and oil products from water in the amount of 20 times more than its mass. When adsorption process is finished plastic foam can be recovered mechanically or washing with solution and repeatedly used [46]. It should be noted that like other sunthetic materials, the toxicity of plastic foams limits their use.

The main advantages of porous textiles and thermoplastic polymers treated with hydrophobic materials are in their high adsorption capacity with respect to oil and repeatedly use after regeneration. Their microbiological degradation during storage and use in filteringmaterials are main inadvantages of these materials.

Analysis of literature showed that the use of fibers prepared on the basis of thermoplastic waste (polyethylene, polypropylene and etc.) is expedient for this purpose. Depending on the method of preparation, such type of adsorbents can have $50-70 \%$ of their initial adsorbtion capacity even after 10-15 phases of repeatedly use [45].

The modified adsorbents having low specific weight and high adsorption capacity are used for water purification during the last years. Composition based on the poliethylene and polypropylene processing wastes and aged rubber tires as well as biopreparations consisting of various oil oxydizing microorganism, biosurfactants and biogenic compounds were proposed for the oil polluted industrial waste water treatment $[11,47]$.

One of the aims of our early researches was to develop an effective method of water purification from oil pollutants. The principle of the method was the use of a new adsorbent consisting of linear cyclopentadiene oligomer (CPDO) having the molecular weight of 4000 5000. The adsorbent was synthesized by oligomerization of cyclopentadiene obtained as by-product at ethylene-propylene production plant in the presence of the Lewis acid catalytic system. In order to make the oligomer floatable and hydrophobic, it was treated with a $5 \%$ solution of polynorbornylacrylate.

The adsorption capacity of CPDO was studied using the solutions prepared by adding oil from different oil fields of the Absheron peninsula and the adsorbent to the distilled, fresh, and sea water. The adsorbent was used in the form of powder with $0.78 \mathrm{~g} / \mathrm{cm}^{3}$ its specific weight. 
According to the results of experiments, $1 \mathrm{mg}$ of the adsorbent adsorbs from the distilled, fresh and sea water about 5, 6, and 7 $\mathrm{mg}$ of oil, respectively. The results showed that when the duration of the CPDO contact with oil increases from 10 to $30 \mathrm{~min}$., oil adsorption increases from 20 to $34.8 \%$. Further increase of the contact duration does not result in the adsorption efficiency. This implies that the optimal contact duration of the adsorbent with oil is $30 \mathrm{~min}$.

The regeneration of adsorbent performed with the petroleum ether. The adsorption capacity of CPDO after its regeneration was $6.1 \mathrm{~g}$ (i.e. $87.1 \%$ ).

On the basis of mathematical statistical study of the experiment results, a regression model was developed to determine the optimal regimes of the process.According to the model, the optimal values of key parameters was determined as following: process duration -30 min., CPDO quantity $-1 \mathrm{mg}$ and the quantity of oil $-5 \mathrm{mg}$ that corresponds to the maximum removal of oil from water $-98 \%$.

The studied CPDO adsorbent was tested in laboratory conditions for the purification of oil polluted water samples in the territory of oil and gas fields [48]. Stations for sampling were selected in discharge channels and lakes in the territory of oil and gas fields, as well as in the coastal part of the Caspian Sea. The results of laboratory tests are shown in table 5 .

Table 5. The results of oil polluted water purification using CPDO (CPDO quantity $-2 \mathrm{mg}$, duration - $30 \mathrm{~min}$.)

\begin{tabular}{|c|c|c|}
\hline $\begin{array}{c}\text { Sampling } \\
\text { stations }\end{array}$ & \multicolumn{2}{|c|}{ Oil quantity, mg/l } \\
\hline & before treatment & after treatment \\
\hline 1 & 2.6 & 0.0 \\
\hline 2 & 15.9 & 4.08 \\
\hline 3 & 0.73 & $0 / 0$ \\
\hline 4 & 5.1 & 0.3 \\
\hline 5 & 1.2 & 0.0 \\
\hline 6 & 1.5 & 0.0 \\
\hline 7 & 7.6 & 1.1 \\
\hline 8 & 0.5 & 0.0 \\
\hline 9 & 80.0 & 54.2 \\
\hline 10 & 6.4 & 0.9 \\
\hline
\end{tabular}

The results of the laboratory tests showed that CPDO is not water-soluble and no changes occur in its chemical composition during long-term storage. It was established that in case of burning the adsorbent with adsorbed oil no carcinogenic substances were formed. No negative effect of CPDO on aquatic organisms (hydrobionts) was recorded during the laboratory tests conducted in the institute of Physiology of AS.

The examined adsorbent CPDO can be used for purification of lakes, seas from oil and oil products and also in the local water treatment in oil refineries.

In the recent years, the use of so called advanced oxidation processes (AOP)for the decontamination of toxic chemicals such as heavy metals, oil and oil products, persistent organic pollutants including pesticides, PCBs and other chemicals attracted great interest of specialists engaged in this field. AOP degrade the organic pollutants into harmless substances under moderate conditions.

Photocatalysis is one of these processesin which the catalyst changes the speed of chemical reactions under the light effect [49]. Despite some lighting costs, photocatalytic removal of organic pollutants from wastewater has considerable ecological and economical advantages over conventional methods in long-term application [50, 51]. Semiconductors are the substances used in photocatalysis. Due to their electronic structure, which is characterized by a filled 
valence band and an empty conduction band, semiconductors (metal oxides or sulfides) can act as sensitizers for light-induced redox processes. Among the various nanomaterials used for photocatalysis titanium dioxide$\mathrm{TiO}_{2}$ is the most usual one due to its availability and high stability[52]. $\mathrm{TiO}_{2}$ exists in three crystalline modifications: rutile, anatase, and brookite. $\mathrm{TiO}_{2}$ is a semiconductor with a band gap energy $\mathrm{Eg}$ of $3.2 \mathrm{eV}$. If this material is irradiated with photons of the energy $>3.2 \mathrm{eV}$ (wavelength $\lambda<388 \mathrm{~nm}$ ), the band gap is exceeded and an electron is promoted from the valence to the conduction band. The consequent process is the chargecarrier generation:

$$
\begin{aligned}
& \mathrm{TiO}_{2}+2 \mathrm{~h} v \rightarrow 2 \mathrm{e}^{-}+2 \mathrm{~h}^{+} \\
& \mathrm{H}_{2} \mathrm{O}+2 \mathrm{~h}+\rightarrow 1 / 2 \mathrm{O}_{2}+2 \mathrm{H}^{+}
\end{aligned}
$$

We investigated photocatalysis method for detoxification and removal of organic compounds from industrial wastewater and oil polluted soils. Two types of $\mathrm{TiO}_{2}$ catalyst were used in the experiments: $\mathrm{TiO}_{2}$ having a size near to nanoparticles (about 3 - 4 microns) and the nanostructured $\mathrm{TiO}_{2}$.

The experiments were carried out in laboratory conditions using industrial waters having different composition of organic pollutants. Initial laboratory tests were conducted with oil industrial wastewater. The samples were collected from the territory of oil production enterprises. To evaluate the degradation rate of organic compounds chemical oxygen demand(COD) was measured before and after each experiment.

Based on the data derived from experiments, a removal efficiency- $\mathrm{R}$ of organic pollutants was calculated according to the following formula:

$$
\mathrm{R}=\frac{[C O D]_{0}+\left[C O D_{t}\right.}{C O D_{0}}
$$

where, $[\mathrm{COD}] 0$ and $[\mathrm{COD}] \mathrm{t}$ are the initial and at any irradiation time COD values.

The first series of experiments were carried out with wastewater having an initial value of COD $8000 \mathrm{mg} / \mathrm{l}$ using $\mathrm{TiO}_{2}$ catalyst with a size near to nanoparticles. The dependence of organic pollutants degradation on both the catalyst concentration and the process duration were studied.

The experiments were carried out in a cylindrical vessel with the capacity of about $500 \mathrm{ml}$ located on the magnetic mixer to provide well-mixing of the catalyst and wastewater. A visible lamp of 300 positioned at a $15 \mathrm{~cm}$ distance above wastewater was used as light source.

The results of experiments conducted
With $0.002,0.005,0.1$ and $0.5 \mathrm{mg}$ of $\mathrm{TiO}_{2}$ catalyst have shown that the value of COD was reduced from 8000 to5760 mg/l. About $40 \%$ of organic pollutants degradedwith $0.5 \mathrm{~g}$ of $\mathrm{TiO}_{2}$ within 120 min. duration of photocatalysis. The experiments have shown that further increase of $\mathrm{TiO}_{2}$ concentration did not significantly change the COD value.

The next stage of studies was conducted to find the influence of photocatalysis duration on the degradation of organic compounds using the wastewater sample obtained from the last experiment, i.e. having COD of $5760 \mathrm{mg} / \mathrm{l}$ and at constant concentration of the catalyst $-0.5 \mathrm{mg}$. The results are presented in table 6 .

Table 6. Effect of photocatalysis duration on COD reduction in oil polluted wastewater

\begin{tabular}{|c|c|c|}
\hline Time, minute & $\mathrm{TiO}_{2}, \mathrm{~g}$ & $\mathrm{COD}, \mathrm{mg} / \mathrm{l}$ \\
\hline 120 & 0.5 & 5760 \\
\hline 180 & 0.5 & 4530 \\
\hline 240 & 0.5 & 3800 \\
\hline
\end{tabular}




\begin{tabular}{|l|l|l|}
\hline \hline 300 & 0.5 & 3600 \\
\hline 360 & 0.5 & 3200 \\
\hline
\end{tabular}

The data derived from the experiments show that the process duration influences COD reduction to some extent. The value of COD was reduced from 5760 to 3200 within 360 minutes, i.e. 6 hours. Overall, no significant reduction was observed in COD value of industrial wastewater during the experiments. This can be attributed mainly to the low degradability of some hydrocarbons by $\mathrm{TiO}_{2}$ with 3 - 4 microns particle size. Only 60\% $65 \%$ removal can be achieved with this type of $\mathrm{TiO}_{2}$ catalyst during 6 hours illumination. Another part of experiments was carried out to study the effect of nanostructured $\mathrm{TiO}_{2}$ catalyst (with a size of $15 \mathrm{~nm}$ ) on the removal of organic compounds from water. The samples were collected fromthe wastewater stream of an olive oil production factory.

Two types of light source including an UV light lamp and a 50 watt visible light lamp were used in the experiments. Figure 2 illustrates the calculated values of $\mathrm{R}$ under different light sources.

As can be seen from Fig. 2, high degradation of organic pollutants is achieved in the presence of visible light, especially within 60-120 minutes of illumination. Thus, the use of $\mathrm{TiO}_{2}$ nanoparticles in photocatalytic process allows better adsorption of organic compounds on the catalyst surface facilitating their effective removal from wastewater [53].

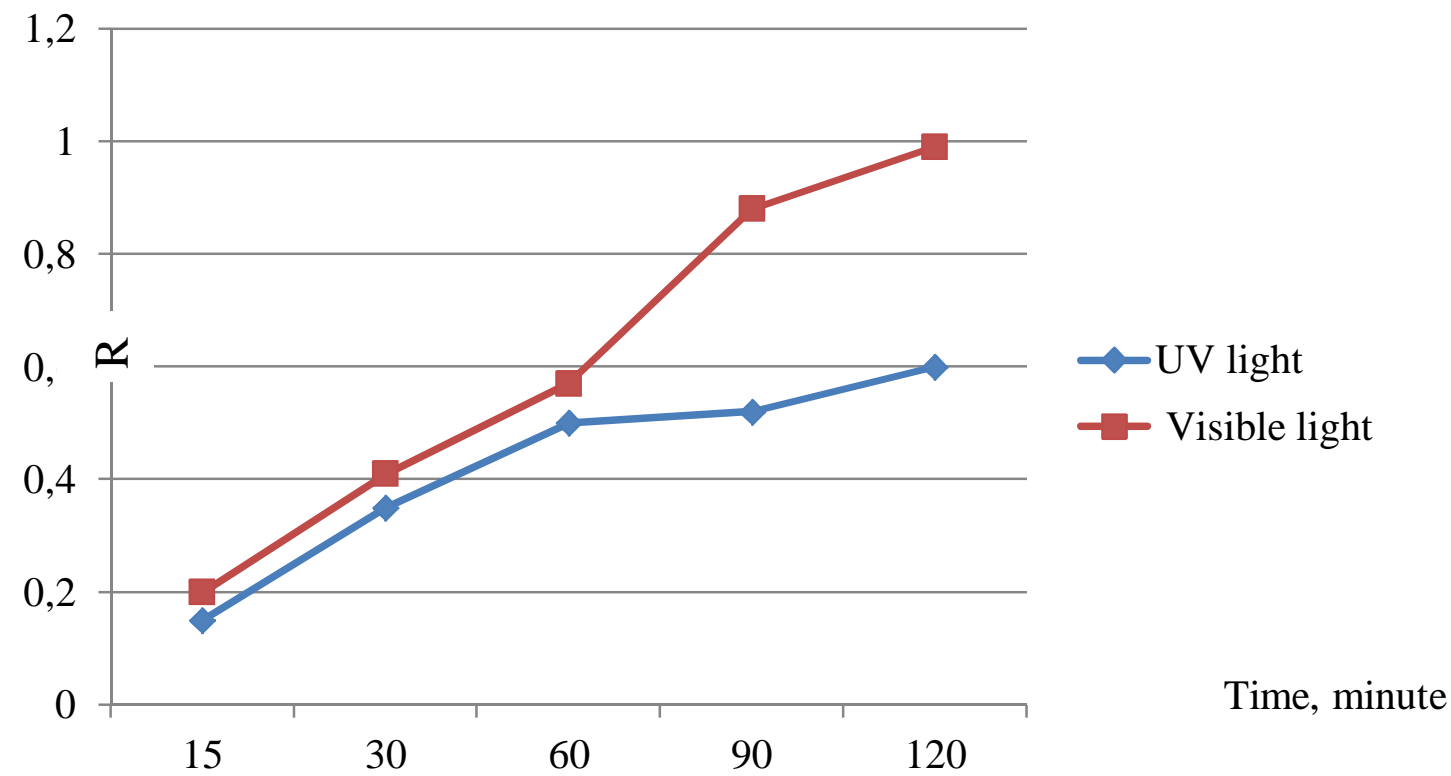

Fig. 2 Removal efficiency of organic pollutants using $\mathrm{TiO}_{2}$ nanoparticles under UV and visible light irradiation

The studies carried out with $\mathrm{TiO}_{2}$ particles 3-4 microns in size demonstrated low degradation of organic compounds under 6 hours duration of photocatalytic process. The results have shown that $99 \%$ removal of organic pollutants can be achieved with the use of $\mathrm{TiO}_{2}$ nanocatalyst within $120 \mathrm{~min}$.

Along with the advantages of the use of nano technologies, there are a number of studies related to their negative impact on ecosystem and human health. The wide scale use of nano particles in the production of food staff and medicals can cause serious disasters for living organisms because of their interaction with biological molecules.Besides, during the use of nanosized (1-100 nm) particles they can be accumulated in organism through respiratory organs resulting in the occurrance of some disseases [54, 55]. 
It is therefore important, to take certain preventive measures before the application of $\mathrm{TiO}_{2}$ nanoparticles .

During the cleaning of soils contaminated with organic compounds by photocatalysis $\mathrm{CO}_{2}$ and water are produced as a result their oxidation. The studies of specialists showed that little amount of $\mathrm{TiO}_{2}$ in soils intensifies the take up of nutrients by cereals. The researches have proved that the presence of $\mathrm{CO}_{2}$ and $\mathrm{TiO}_{2}$ in soil in certain ratio increase cereal fertility [56].

In our studies on oil polluted soil clening we used for the first time $\mathrm{TiO}_{2}$ catalyst having a size near to nano particles like in the previous experiments carried out for organic polluted wastewater treatment. Soils constituting of about $20 \%$ petroleum hydrocarbons were used in laboratory tests. The quantity of catalyst, light intensity and soil humidity are the key factors influencing the efficiency of photocatalysis process.

In order to determine the optimal amount of catalyst we added $0.1 ; 0.2 ; 0.4$ and $0.5 \mathrm{~g} \mathrm{TiO}_{2}$ into Petri dishes each containing 5 $\mathrm{g}$ of hydrocarbon polluted soil sample. Then the samples were mixed with $5 \mathrm{ml}$ distelled water and illuminated under visible light during 3 hours. The degree of hydrocarbons degradation was determined according to the reduction of their concentrations in soil samples by thermographic method.

The results of experiments indicated that the increase of the amount of $\mathrm{TiO}_{2}$ catalyst allowed removing only $33 \%$ of hydrocarbons from soils at 3 hours duration of process.

Along with the above mentioned parameters, the efficiency of photocatalysis is also dependent on $\mathrm{pH}$, the pollution degree and type of pollutants as well as the illumination time. To determine the effect of the process duration on the hydrocarbons degredation we increasedthe experiment duration to 6 hours under constant values of other parameters. The degradation and reduction of the amount of pollutants in soil samples was detected in thermographic analyzer. Analysis of the experiment data showed that 6 hours duration of photocatalysis resulted in reducing the hydrocarbons' amount in soils to $42 \%$. Despite some positive results were obtained during the studies with 3-4 microne size $\mathrm{TiO}_{2}$ catalyst, experiments have shown that this type of catalyst is not effective for cleaning the soils polluted with petroleum hydrocarbons.

More promisable results were derived from laboratory experiments when we used $\mathrm{TiO}_{2}$ with $21 \mathrm{~nm}$ size for oil polluted soil cleaning by photocatalysis method. A number of researchs have shown that the concentration of $\mathrm{TiO}_{2}$ catalyst essentially influences the hydrocarbons removal from soils. According to authors [57], the optimal amount of $\mathrm{TiO}_{2}$-in is $2 \%$. But, the majority of researches confirm that compared to $2 \%$, photocatalysis with $5 \%$ $\mathrm{TiO}_{2}$ proceeds more efficiently.

Therefore, our experiments was first focused on the study of the effect of catalyst concentration on the degradation of hydrocarbons in soil. $100 \mathrm{mg}$ of oil contaminated soil was poured into 5 Petri dish added with $1,2,3,4$ and $5 \% \mathrm{TiO}_{2}$ and irradiated under a 125-watt UV lamp durung 180 min. As it is known that high soil moisture speeds up the photocatalysis process, $100 \mathrm{ml}$ of water (or about $30 \% \mathrm{H}_{2} \mathrm{O}_{2}$ ) was added to the soil at intervals to provide the required moisture content.

Studies showed that the optimal amount of catalyst for purifying soil containing 120$150 \mathrm{mg} / \mathrm{kg}$ hydrocarbon is about 5\% (Fig. 3).

Research of experts indicate that soil humidity is an important factor in the organic matter decomposition [58, 59]. As the humidity increases, the rate of pollutants degradationincreases considerably. Experiments have shown that $2 \%$ of catalyst is sufficient for, at least, $80-85 \%$ decomposition of some organic chemicals. It has been observed that $70 \%$ of several PAH decompose even with the addition of $1 \%$ catalyst. Therefore, in most cases, $2 \%$ of $\mathrm{TiO}_{2}$ is considered optimal for the decomposition of organic compounds. Studies have shown that the decomposition of such PAH as pyrene, phenanthrene, fluoranthene and anthracene, proceeds well with $2 \% \mathrm{TiO}_{2}$ in soils having sufficient humidity. 


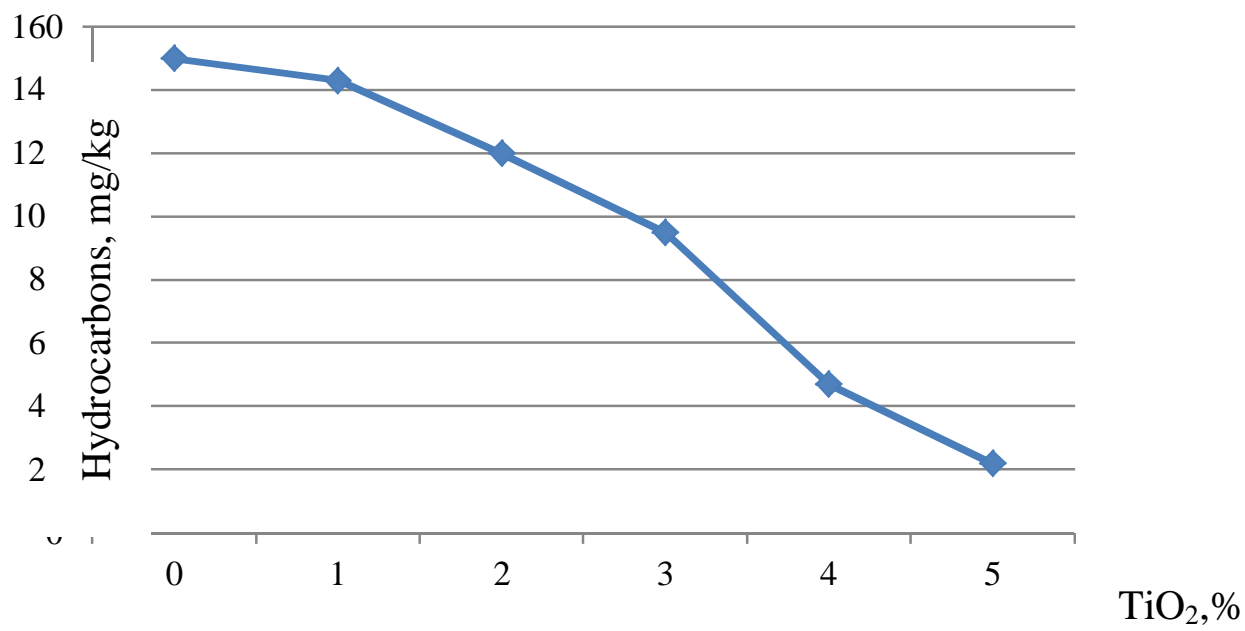

Fig. 3. Effect of nanosized $\mathrm{TiO}_{2}$ content on the degradation of oil hydrocarbons

In order to study the effect of soil humidity on the process, $200 \mathrm{mg}$ of oil contaminated soil was mixed with $2 \% \mathrm{TiO}_{2}$ catalyst and irradiated under UV lamp for $6 \mathrm{~h}$ by gradually adding $0,20,50,80$ and $100 \mathrm{ml}$ of water, so the amount of oil was determined.

Laboratory experiments were repeated under the same conditions to investigate the effect of replacement of water with hydrogen peroxide $\left(\mathrm{H}_{2} \mathrm{O}_{2}\right)$ on the removal of organic compounds from soil. $10 \mathrm{ml}$ of $\mathrm{H}_{2} \mathrm{O}_{2}$ was added to the oil contaminated soil that was hydrated by mixing with $10 \mathrm{ml} \mathrm{H}_{2} \mathrm{O}_{2}$ each time when dried after being irradiated for a period of time. The results indicate that the effect of $\mathrm{H}_{2} \mathrm{O}_{2}$ is not much different compared to the experiments carried out with water.

\section{Conclusion}

Taking into account the abovestated, it can be concluded that the production and use of traditional energy sources, the continuous widescale urbanization and the development of transport infrastructure have resulted in the release of a huge amount of harmful chemicals, including oil, polyaromatic hydrocarbons, heavy metals, radionuclides, PXBs and poisonous gases into the environment. Being subjected to various changes, depending on the natural conditions, these compounds negatively affect the people health, flora and fauna of the area causing a number of local, regional and global problems. The development of advanced technologies, taking into account the pecularities of pollutants to avoid contamination of the environment with harmful compounds, is an urgent problem of todays. Studies show that the use of environmentally friendly adsorbents for the oil polluted wastewater treatment is one of the most effective ways to solve the problem. The proposed in the article new method based on the application of adsorbent made from the linear oligomer of cyclopentadiene is very useful in terms of high adsorption capacity of this compound, which does not adversely affect the environment and living organisms and produces no toxic substances when burned.The study of photocatalysis method using the nanoparticles of $\mathrm{TiO}_{2}$ catalyst for the purification of water and soils polluted with oil hydrocarbons and other organic compounds has shown that the application of this method allows to remove 90$95 \%$ of polyaromatic hydrocarbons, phenols and other organic chemicals from soils and industrial wastewater. Considering the fact that the process does not require high energy and occurs under the sun's rays, it is possible to achieve effective results through the application of photocatalysis method for the oil-contaminated soils cleaning in the Absheron conditions. 
1. Remorov V.V., Sidorenko T.N., Bushkovsky A.L. The main factors of man-caused environmental disruption in the oil-producing regions of the Tomsk region. Neftyanoe Khozyaystvo - Oil Industry. 1996, no.11, pp. 90-91. (In Russian).

2. Khalilova H.Kh, Mamedov V.A. The assessment of anthropogenic impact on heavy metal pollution of soils and sediments in urban areas of oil industrial region of Azerbaijan. Polish Journal of Environmental Studies, 2016, vol. 25, no. 1, pp. 159-166.

3. Khalilova H. Kh. Impact of hydrocarbon pollution on biochemical characteristics of aquatic ecosystems. Chemical Problems, 2016, no. 2, pp. 146-152.

4. Westerlund C., Viklander M. Pollutant release from a disturbed urban snowpack in northern Sweden. Water Quality Research Journal of Canada, 2011, vol.46, no. 2, pp. 98-109.

5. Kasymov A. G., Askerov F. S. Biodiversity: Oil and biological resources of the Caspian Sea. Baku:"PrintStudio" Publ, 2001, 326 p.

6. Kajiwara N., Watanabe M., Niimi S. et al. Persistent organic pollutants (POPs) in the Caspian seals of unusial mortality event during 2000 and 2001. J. Environ.Pollut., 2008, no. 152 (2), pp. 431-442.

7. Khalilova H.Kh. Assessment of anthropogenic impact on polycyclic aromatic hydrocarbons pollution in aquatic ecosystems. Journal of Baku Engineering University, Chemistry and Biology,2017, vol. 1, no.1, pp. 22-28.

8. Mukhtarov A.K. Environmental pollution associated with oil and petroleum products. Oil and Gas, 2000, no. 2, pp. 114-117. ( In Kazakhstan).

9. Solntseva N.P. General patterns of soil transformation in oil production areas. In the book: Restoration of oil-contaminated soil ecosystems. Moscow: Nauka Publ., 1988, pp. 23-42.

10. Khalilova H.Kh. Classification of environmental pollutants in the development of oil and gas fields on the example of the Absheron Peninsula. Azerbaijan Neft Teserrufatı - Azerbaijan oll industry. 2013, no. 12, pp. 58-63. (In Azerbaijan).

11. Kahramanli Yu.N. Foam polymer oil sorbents. Environmental problems and their solutionsBaku: Elm Publ., 2012, 305 p.

12. Kouakou L., Abolle A., Planche H.Study of contaminants stemmed from the waste water of the Ivorian refining company. J.Energy and environment, 2010, vol. 1, no. 6, pp. 999-1008.

13. Teplaya G.A. Heavy metals as a factor in environmental pollution. Astrakhan Journal of Environmental Education. 2013, no. 1 (23), pp. 182-192. (In Russian).

14. Khalilova H.Kh. Pollution of soil and groundwaters with hydrocarbons and heavy metals in a zone of influence of the oil industrial waste. Processes of Petrochemistry and Oil Refining, 2016, vol. 7, no. 2 (66), pp. 160-167.

15. Aliyev M.I. Ecological monitoring of the Caspian Sea. Baku: 2009, 290 p. (In Azerbaijan).

16. Rogozina E.A. Actual problems of the cleaning of oil-contaminated soils. Oil and Gas Geology. Theory and Practice, 2006, no. 1, p. 1-11. (In Russian).

17. Ismailov N.M. Remediation of oilcontaminated soil and drill cuttings. Baku: Elm Publ., 2006, 144 p.

18. Khalilova H.Kh. The impact of oil contamination on soil ecosystem. $J$. Biological and Chemical Research, 2015, vol. 2, no. 3, pp. 133-139.

19. Aliyev F., Khalilova $H$. The anthropogenic impact on surface water resources in Azerbaijan. J. Energy and Environment, 2014, vol. 25, no. 2, pp. 343-356.

20. Adesina G., Adelasoye K. Effect of crude oil pollution on heavy metal contents, microbial population on soils, and maize and cowpea growth. Agricultural sciences. 2014, vol. 5, no. 1, pp.43-50. 
21. Faksness L., Grini P., Dalings P. Partitioning of semi-soluble organic compounds between the water phase and oil droplets in produced water. Marine Pollution Bulletin, 2004, 48, pp. 731-742.

22. Hites R., Laflamme R., Farrington J. Sedimentary polycyclic aromatic hydrocarbons: The historical record. Science, 1977, no. 198, pp. 829-831.

23. Salmanov M.A. Ecology and biological productivity of the Caspian Sea. Baku: Elm Publ., 1989, 398 p. (In Azerbaijan).

24. Verrhiest G., Clement B., Volat B. et al. Interactions between a polycyclic aromatic hydrocarbon mixture and the microbial communities in a natural freshwater sediment. Chemosphere, 2002, no. 46, pp.187-196.

25. Vara S., Bandaru P., Karthik A. Petroleum hydrocarbon contamination in urban soils, a case study. International Journal of Research and Reviews in Pharmacy and Applied science, 2013, no. 2(1), pp.90-101.

26. Khalilova H.Kh. Adverse effects of air pollution by toxic emissions in industrial regions using the example of the Absheron Peninsula. Problemi energetiki - Problems of Energy, 2014, no. 2, p. 64-72. (In Russian).

27. Kazimov M.A., Akhmedzade L.A. Features and hygienic assessment of soil pollution by automobile emissions. Azerbaijan Medical Journal. 2006, no. 4, pp. 96-99.

28. Qiu H. Migration mechanism of organic pollutants in national water-body sediments. Geopgraphy and Geology, 2011, vol. 3, no. 1, pp 239-246.

29. Mayer T., Rochfort Q., Marsalek J.et al. Environmental characterization of surface runoff from three highway sites in Southern Ontario, Canada: 1. Chemistry. Water Quality Research Journal of Canada, 2011, vol. 46, no. 2, pp. 110-120.

30. Ozone in the United Kingdom. $5^{\text {th }}$ report of the Air quality expert group. Department of the Environment, Food and Rural affairs, London 2009, 239p.

31. Safe S. Polychlorinated biphenyls (PCBs), dibenzo-p-dioxins

(PCDDs) dibenzofurans (PCDFs) and related compounds:

Environmental

and mechanistic considerations which support the development of toxic equivalency factors (TEFs) CRC Crit. Rev. Toxicol. 1990, vol. 21, pp 51-88.

32. Khakimov F.I., Deeva N.F., Ilyina A.A. Polychlorinated biphenyl pollution of the soil of the city of Serpukhov. Soil Science, 2003, no. 4, pp. 493-498. (In Russian).

33. Popova A.Yu., Trukhina G.M. Chlorinated biphenyls are a hygienic problem of our time. Moscow, 2000, 244 p.

34. Masson O., Baeza A., Bieringer J. et al. Tracking of airborne radionuclides from the damaged Fukushima Daiichi nuclear reactors by European Networks. Environ. Sci. Tech., 2011, vol. 45, no.18, pp. 76707677.

35. Molchanova I.V., Mikhailovskaya L.N., Pozolotina V.N. and others. Technogenic pollution of soil and vegetation in the south of Primorsky Krai. Ecology, 2013, no. 5, pp. 334-338. (In Russian).

36. Yoshida N., Kanda J. Tracking the Fukushima Radionucludes. Science, 2012, vol. 336, pp. 1115-1116.

37. Bakr W. Assessment of the radiological impact of oil refining industry. Journal of Environ. Radioactivity, 2010, no. 101, pp. 237-243.

38. El Afifi E., El-Reefy S., Aly H. Treatment of solid waste containing Ra226. Arab Journal of Nucl. Sci. Appl., 2006, no. 39, pp. 35-47.

39. White G., Rood A. Radon emanation from NORM contaminated pipe scale and soil at petroleum industry sites. $J$. Environmental Radioactivity,2001, vol. 54, pp. 401-413.

40. Betti M., Aldave de las Heras L., Janssens A. Results of the European Commission Marina II Study Part - effects of discharges of naturally occurring radioactive material. Journal of Environ. Radioactivity, 2004, no. 74, pp. 255- 277.

41. Efendiev G.Kh., Alekperov R.A., Nuriev A.N. Questions of the geochemistry of radioactive elements. Baku: Publishing House of the Academy of Sciences of Azerbaijan, 1964,150 p. 
42. Nuriev A.N. Trace elements of oil water and the possibility of their integrated extraction. Baku: Elm Publ., 1981, 148 p. (In Azerbaijan).

43. Kerimov M.K. Radioactive contamination in the oil fields of the Absheron Peninsula. In the book: Methods for conducting environmental monitoring. Baku, 1998, pp. 19-23. (In Azerbaijan).

44. Khalilova H.Kh. Research into the radionuclide pollution of ecosystem on the territory of oil fields of the Absheron peninsula. Chemical Problems, 2016, no. 3, pp.233-237.

45. Sirotkina E., Novoselova N. Materials for adsorbtion purification of waterfrom petroleum and oil products. Chemistry for sustainable development, 2005, vol.13, pp. 359-375.

46. Mochalova O.S., Gurvich L.M., Antonova N.M. Methods of dealing with accidental pollution of water bodies. Environmental protection in the oil and gas sector. 2004, no. 3, pp. 20-25. (In Russian).

47. Khalilova H.Kh., Mamedov M.K. The method of purification of oil from water pollution. Journal of Water and Technology. 2008, vol. 30, no. 3, pp. 339344.

48. Khalilova H.Kh. The study of water purification from oil pollution. Chemical industry, 2013, vol. 90, no. 1, pp. 45-49. (In Russian).

49. Ibrahimova S.A, Aliyev F.G., Stoller M., Chanese A. Optimal configuration of a photocatalytic lab-reactor by using immobilized nanostructured $\mathrm{TiO}_{2}$. Chemical Engineering Transactions, 2016, vol. 47, pp. 199-204.

50. Shahrezaei F., Akhbari A. and Rostami A. Photodegradation and Removal of Phenol and Phenolic Derivatives from Petroleum Refinery Wastewater Using Nanoparticles of $\mathrm{TiO}_{2}$. J. Energy and Environment, 2012, vol. 3, no. 2, pp. 267-274.

51. Tu, W., Lin, Y.-P. and Bai, R. Removal of Phenol in Aqueous Solutions by Novel Buoyant Composite Photocatalysts and the
Kinetics. Separation and Purification Technology, 2013, vol. 115, pp. 180-189.

52. Hashimoto K., Irie H., Fujishima Akira. $\mathrm{TiO}_{2}$ Photocatalysis: A Historical review and Future Prospects. Japanese journal of Applied Physics, 2005, vol. 44, no.12, pp. 8269-8285.

53. Khalilova H.Kh., Hasanova S.A., Aliyev F.G. Photocatalytic removal of organic pollutants from industrial wastewater using $\mathrm{TiO}_{2}$ catalyst. Journal of Environmental Protection, 2018, no. 9, pp. 691-698.

54. I.-L. Hsiao and Y.-J. Huang. Effects of various physicochemical characteristics on the toxicities of $\mathrm{ZnO}$ and $\mathrm{TiO}_{2}$ nanoparticles toward human lung epithelial cells. Science of the Total Environment, 2011, vol. 409, no. 7, pp. 1219-1228.

55. Bhatt I. and Tripathi B.N. Interaction of engineered nanoparticles with various components of the environment and possible strategies for their risk assessment. Chemosphere, 2011, vol. 82, no. 3, pp. 308-317.

56. Jiang F, Shen Y, Ma C, Zhang X, Cao W, Rui Y. Effects of $\mathrm{TiO}_{2}$ nanoparticles on wheat (Triticumaestivum L.) seedlings cultivated under super-elevated and normal $\mathrm{CO}_{2}$ conditions. PLoS ONE, 201712(5): e0178088. https://doi.org/10.1371

57. Dong D., Gu J., Kong L., Zheng Y., Li X. Photocatalytic degradation of phenanthrene on soil surfaces in the presence of nanometer anatase $\mathrm{TiO}_{2}$ under UV-light. Chemical Engineering Journal, 2010, vol. 158, issue 3, pp. 378-383.

58. Karam F.F., Hussein F. H., Baqir S. J. et al. Photocatalytic degradation of anthracene in closed system reactor. International Journal of Photoenergy, vol. 2014, pp.24-30.

59. Rocha, O. R. S., Duarte, M. M. M. , Dantas, R. F. et al.Oil sludge treatment by solar tio2-photocatalysis to remove polycyclic aromatic hydrocarbons (PAH). Brazilian journal of petroleum and gas, 2014, vol. 8, no. 3, pp. 089-096. 


\title{
KIMYOVI ÇIRKLONDIRICILORIN OTRAF MÜHITO MONFI TOSIRI PROBLEMLORI VO ONLARIN QARŞISININ ALINMASI YOLLARI
}

\author{
H.X. Xolilova ${ }^{1,2}$ \\ ${ }^{1}$ AMEA Fizika Institutu \\ AZ 1143, Bakl, H. Cavid pr.33 \\ ${ }^{2}$ Beynalxalq Ekoenergetika Akademiyast \\ Az 1073, Bakı, M. Rahim küç. 5; e-mail: khalilova@rambler.ru
}

Maqalada atraf mühitin zararli kimyavi maddalarla çirklanmasi va onların ekosistemin komponentlarina manfi tasiri problemi müzakira olunur. Atmosfer havast, torpaq va su hövzəlarina sənaye müəssisalərindən atılan toksik üzvi birləşmələr, ă̆ır metallar və radionuklidlarin, hamçinin naqliyyatın ixrac qazlarının tabii mühit və canlı orqanizmlar üçün

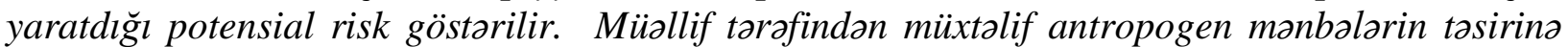
məruz qalan arazilardo atraf mühitin qeyd olunan kimyəvi maddəlarla çirklonməsi vo onun qarşısının alınmasının səmərəli üsulları sahəsində aparılmış tədqiqatların nəticalori təqdim edilir.

Açar sözlar: neft, kimyəvi çirklandiricilar, ekosistem, radionuklidlar, adsorbsiya, fotokataliz

\section{ПРОБЛЕМЫ НЕГАТИВНОГО ВОЗДЕЙСТВИЯ ХИМИЧЕСКИХ ЗАГРЯЗНИТЕЛЕЙ НА ОКРУЖАЮЩУЮ СРЕДУ И ВОЗМОЖНЫЕ ПУТИ ИХ ПРЕДОТВРАЩЕНИЯ}

\author{
Х.Х. Халилова ${ }^{1,2}$ \\ ${ }^{1}$ Институт физики Начиональной АН Азербайджана \\ AZ 1143, Баку, пр. Г. Джавида, 33 \\ ${ }^{2}$ Международная Экоэнергетическая Академия \\ AZ 1073, Бакy, ул. M. Рахима, 5; e-mail: khalilova@rambler.ru
}

В статье рассматривается проблема загрязнения окружающей среды вредными химическими веществами и их негативного воздействия на компоненты экосистемьл. Показаны основные источники вредных химикатов, выбрасываемых в атмосферный воздух, землю и водные бассейны. Обсуждаются потенщиальные угрозы для природной среды и живых организмов токсичных органических веществ, тяжельх металлов, радионуклидов, а также выхлопных газов. Представлены результаты исследований автора в области загрязнения окружающей среды на территориях, подверженных воздействию различных антропогенных источников и эффективных методов предотвращения негативного воздействия на окружающую среду.

Ключевые слова: нефть, химические загрязнители, экосистема, радионуклиды, адсорбиия, фотокатализ 